\title{
Filamin $A$ is reduced and contributes to the CASR sensitivity in human parathyroid tumors
}

\author{
Alessandra Mingione1, Chiara Verdelli2, Stefano Ferrero3, Valentina Vaira4, \\ Vito Guarnieri5, Alfredo Scillitani6, Leonardo Vicentini7, Gianni Balza8, \\ Edoardo Beretta ${ }^{9}$, Annalisa Terranegra10, Giuseppe Vezzoli11, Laura Soldati1 and \\ Sabrina Corbetta ${ }^{12}$ \\ ${ }^{1}$ Department of Health Sciences, University of Milan, Milan, Italy \\ 2Laboratory of Experimental Endocrinology, IRCCS Istituto Ortopedico Galeazzi, Milan, Italy \\ ${ }^{3}$ Division of Pathology, Department of Biomedical, Surgical and Dental Sciences, University of Milan, \\ Fondazione IRCCS Ca' Granda Ospedale Maggiore Policlinico, Milan, Italy \\ ${ }^{4}$ Division of Pathology, Department of Pathophysiology and Transplantation, University of Milan, \\ Fondazione IRCCS Ca' Granda Ospedale Maggiore Policlinico and Istituto Nazionale Genetica \\ Molecolare (INGM) Romeo ed Enrica Invernizzi, Milan, Italy \\ ${ }_{5}^{5}$ Medical Genetics, IRCCS Hospital Casa Sollievo della Sofferenza, San Giovanni Rotondo (FG), Italy \\ ${ }^{6}$ Endocrine Unit, IRCCS Hospital Casa Sollievo della Sofferenza, San Giovanni Rotondo (FG), Italy \\ TEndocrine Surgery, IRCCS Fondazione Ca' Granda Ospedale Maggiore Policlinico, Milan, Italy \\ ${ }^{8}$ Internal Medicine Unit, A.O. Alessandro Manzoni, Lecco, Italy \\ ${ }^{9}$ Endocrine Surgery, IRCCS Ospedale San Raffaele, Milan, Italy \\ ${ }^{10}$ Sidra Medical and Research Center, Doha, Qatar \\ ${ }^{11}$ Nephrology and Dialysis Unit, IRCCS Ospedale San Raffaele, Milan, Italy \\ ${ }^{12}$ Endocrinology Service, Department of Biomedical Sciences for Health, University of Milan, IRCCS \\ Istituto Ortopedico Galeazzi, Milan, Italy
}

Correspondence should be addressed to L Soldati or S Corbetta Email

laura.soldati@unimi.it or sabrina.corbetta@unimi.it

\begin{abstract}
Parathyroid tumors display reduced sensitivity to extracellular calcium $\left(\left[\mathrm{Ca}^{2+}\right]_{0}\right) \cdot\left[\mathrm{Ca}^{2+}\right]_{0}$ activates calcium-sensing receptor (CASR), which interacts with the scaffold protein filamin A (FLNA). The study aimed to investigate: (1) the FLNA expression in human parathyroid tumors, (2) its effects on the CASR mRNA and protein expression, and (3) on ERK signaling activation, (4) the effect of the carboxy-terminal CASR variants and (5) of the treatment with the CASR agonist R568 on FLNA-mediated ERK phosphorylation in HEK293 cells. Full-length FLNA immunostaining was variably reduced in parathyroid tumors. Immunofluorescence showed that FLNA localized in membrane and cytoplasm and co-localized with CASR in parathyroid adenomas (PAds)derived cells. Cleaved C-terminus FLNA fragment could also be detected in PAds nuclear protein fractions. In HEK293 cells transfected with 990R-CASR or 990G-CASR variants, silencing of endogenous FLNA reduced CASR mRNA levels and total and membrane-associated CASR proteins. In agreement, FLNA mRNA levels positively correlated with CASR expression in a series of 74 PAds; however, any significant correlation with primary hyperparathyroidism severity could be detected and FLNA transcript levels did not differ between PAds harboring 990R or 990G CASR variants. R568 treatment was efficient in restoring 990R-CASR and 990G-CASR sensitivity to $\left[\mathrm{Ca}^{2+}\right]_{0}$ in the absence of FLNA. In conclusion, FLNA is downregulated in parathyroid tumors and parallels the CASR expression levels. Loss of FLNA reduces CASR mRNA and protein expression levels and the CASR-induced ERK phosphorylation. FLNA is involved in receptor expression, membrane localization and ERK signaling activation of both 990R and 990G CASR variants.
\end{abstract}

\author{
Key Words \\ - filamin A \\ - calcium-sensing receptor \\ - parathyroid tumors \\ - primary \\ hyperparathyroidism
}

Journal of Molecular

Endocrinology

(2017) 58, 91-103 


\section{Introduction}

Tumors of the parathyroid glands display reduced sensitivity to extracellular calcium $\left(\left[\mathrm{Ca}^{2+}\right]_{\mathrm{o}}\right)$ resulting in failure in inhibiting parathormone (PTH) synthesis and release. Overall, derangements in calcium sensing result in increased parathyroid cell proliferation. The parathyroid cell sensitivity to $\left[\mathrm{Ca}^{2+}\right]_{0}$ is mediated by the calciumsensing receptor (CASR). CASR is a G-protein-coupled membrane receptor interacting with different intracellular pathways (Breitwieser 2013, Conigrave \& Ward 2013): active CASR dimers increase inositol-triphosphate and intracellular calcium concentrations, activate protein kinase $\mathrm{C}$ and intracellular calcium oscillations and stimulate mitogen-activated protein kinase (MAPK) cascade through p44/42 extracellular signaling-regulated kinase (ERK) phosphorylation (Breitwieser \& Gama 2001, Corbetta et al. 2002, Chakravarti et al. 2012). CASR activates intracellular signaling through direct interaction with $\mathrm{Gq} / 11$ protein and the cytoskeletal scaffold protein filamin A (Awata et al. 2001, Hjalm et al. 2001).

Parathyroid tumors are characterized by variable degrees of insensitivity to $\left[\mathrm{Ca}^{2+}\right]_{0}$, sustained by deregulation of key molecular components of CASR-coupled intracellular signaling: CASR mRNA and protein expression is downregulated (Corbetta et al. 2000, Varshney et al. 2013a); the major 990R allele of the CASR gene is associated with higher serum PTH levels (Corbetta et al. 2006) in hyperparathyroid patients and with in vitro lower responsiveness to $\left[\mathrm{Ca}^{2+}\right]_{\mathrm{o}}$ than the minor CASR 990G allele (Terranegra et al. 2010); $\mathrm{Gq} / 11$ protein expression is reduced (Corbetta et al. 2000); CASR-stimulated p44/42 ERK activity is blunted (Corbetta et al. 2002).

Filamin A (FLNA) is a $280 \mathrm{kDa}$ protein that contains N-terminal actin-binding domain and consists of 24 repeated domains of approximately 96 amino acids each. FLNA is a scaffolding molecule facilitating protein interaction. The C-terminal domains 14 and 15 of FLNA interact with the carboxyl-terminal portion of CASR (Awata et al. 2001, Hjalm et al. 2001). This interaction stabilizes CASR in membrane and reduces its degradation, thereby facilitating the MAPK signaling (Zhang \& Breitwieser 2005). In adult cells, FLNA regulates cell cycle: suppression of FLNA leads to prolongation of the cell cycle, mainly in the $\mathrm{M}$ phase and increases phosphorylation of cyclin-dependent kinase 1 (Lian et al. 2012). Moreover, FLNA plays a significant role in cancer development and progression: a number of human cancers overexpress FLNA. By contrast, in human prolactin-secreting pituitary adenomas resistant to dopamine treatment, a tumor model close to human parathyroid tumors, FLNA expression is diminished and involved in dopamine resistance (Peverelli et al. 2012).

Data about FLNA in parathyroid cells are from neonatal bovine parathyroid glands, whose dispersed cells express endogenously FLNA at confocal immunofluorescence microscopy: FLNA exhibits the highest density within the cytoplasm and colocalizes with endogenous CASR proteins (Hjalm et al. 2001). To our knowledge, data about FLNA expression in human parathyroid cells from normal or tumor glands are still lacking.

In the present study, we investigated: (1) the FLNA expression in parathyroid adenomas and carcinomas samples compared to normal glands from normocalcemic subjects; (2) the effects of FLNA loss on CASR expression, (3) on CASR-activated ERK signaling and (4) in presence of the CASR agonist R568 in HEK293 cells transiently transfected with CASR; (5) whether the 990G-CASR variant expression and function were differently affected by FLNA loss with respect to the 990R variant.

\section{Methods}

\section{Sample collection}

Formalin-fixed paraffin-embedded sections from 4 normal parathyroid glands incidentally removed during thyroid surgery of normocalcemic patients, 17 parathyroid tumors (10 typical parathyroid adenomas and 7 parathyroid carcinomas) from patients with primary hyperparathyroidism (PHPT) were collected and analyzed by immunohistochemistry. Fresh tissue samples from 3 parathyroid adenomas (PAds) were collected, fragmented and the dispersed cells were cultured for immunofluorescence experiments.

\section{Immunohistochemistry (IHC)}

Archival normal and tumor parathyroid samples (6 normal parathyroid glands incidentally removed from normocalcemic patients during surgery for thyroid diseases, 10 sporadic benign PAds and 7 parathyroid carcinomas (PCas) from patients with PHPT) were used for immunohistochemistry after tissues morphology was assessed by haematoxylin and eosin staining. Histological diagnosis of parathyroid carcinoma was established

Published by Bioscientifica Ltd. 
according to WHO published guidelines (Bondeson et al. 2004). Briefly, IHC was performed using an anti-human full-length FLNA antibody (1:200; Abnova Corporation, Taipei City, Taiwan) as previously described (Peverelli et al. 2012). Slides with absence of the primary antibody were included as negative controls. Percentage of positive cells was calculated considering at least 400 cells in the main representative high-power field, as previously described (Lania et al. 2004); blinded scoring of the cells was performed by an experienced pathologist (S.F.).

\section{Immunofluorescence (IF)}

Human PAds-derived cells $(n=3)$ cultured for $48 \mathrm{~h}$ and subconfluent HEK293 cells were fixed in 4\% paraformaldehyde, permeabilized in $0.1 \%$ Triton X-100 and blocked in 1\% BSA-PBS for $2 \mathrm{~h}$. Then, cells were incubated with primary antibodies against human fulllength FLNA (mouse monoclonal H00002316-M01; Abnova Corp.) and human CASR (rabbit polyclonal PA1934; Affinity Bioreagents, Golden, CO, USA), overnight at $4^{\circ} \mathrm{C}$, washed thrice in PBS and followed by incubation with secondary antibodies conjugated with FITC or DyLight549 (1:100; Jackson Immuno Research). Nuclei were stained with Hoechst 33342 (1:500 dilution). For negative controls, PBS was used instead of primary antibodies to exclude unspecific binding of secondary antibody. Images were captured using a fluorescent confocal microscope (TCS SP2, Leica) and a digital camera.

\section{Nuclear cleaved FLNA fragment expression in parathyroid tissues}

Cells were homogenized using a Nuclear Extract kit (Active Motif, Carlsbad, CA, USA) following the manufacturer's instructions to obtain both cytoplasmic and nuclear protein fractions. The kit provide protease and phosphatase inhibitors cocktail for the cell lysis and protein extraction procedures. Samples ( $40 \mu$ g proteins) were denatured with loading dye and $\beta$-mercaptoethanol for $10 \mathrm{~min}$ at $95^{\circ} \mathrm{C}$. Proteins were separated on $10 \% \mathrm{w} / \mathrm{v}$ SDS-PAGE, and antigens were revealed by a primary antibody that recognized the C-terminal (90-100 kDa) calpain cleavage fragment of Filamin A (Millipore). Histone H3 was used as internal control (Abcam). Specific protein bands were detected using SuperSignal West Pico enhanced chemiluminescence system (Pierce).

\section{Quantitative real-time PCR}

Total RNA was extracted from frozen human PAds samples using TRIzol reagent (Thermo Fisher Scientific) following manufacturer's instructions. One microgram of RNA was digested with DNAse I (Thermo Fisher Scientific) to remove genomic DNA contamination and reverse-transcribed using the iScript cDNA Synthesis kit (BioRad). CASR and FLNA expression levels were estimated by quantitative real-time PCR using specific primers: CASR gene (Forward: 5'-ATGCCAAGAAGGGAGAAAGACTCTT-3'; Reverse: 5'-TCAGGACACTCCACACACTCAAAG-3'); FLNA gene (Forward: 5'-CAGTGCTATGGGCCTGGTAT-3'; Reverse: 5-'CCACTTTGTACATGCCATCG-3') and housekeeping GAPDH gene (Forward: 5'-CTCATGACCACAGTCCATGCCATC-3' and Reverse: 5'-CATGCCAGTGAGCTTCCCGTT-3'). Real-time PCR was performed with 7500 Fast Real-Time PCR Systems (Applied Biosystems, Life Technologies) with 100ng of cDNA as template and SYBR Premix Ex Taq II (Takara Bio Inc). Specific temperature of primers annealing were $57^{\circ} \mathrm{C}$ for $C A S R$ gene, $65^{\circ} \mathrm{C}$ for FLNA gene or $60^{\circ} \mathrm{C}$ for GAPDH. Mean cycle threshold values of triplicate samples were used for analysis. Data were analyzed by 7500 Fast System SDS Software. CASR and FLNA mRNA quantities were normalized using the housekeeping GAPDH expression levels, and data were expressed as CASR/GAPDH and FLNA/GAPDH mRNA ratios.

\section{Culture of parathyroid adenomas (PAds)-derived and human embryonic kidney (HEK293) cells}

Samples from human parathyroid adenomas (PAds) were cut into fragments less than $1 \mathrm{~mm}^{3}$, washed with PBS and partially digested with $2 \mathrm{mg} / \mathrm{mL}$ collagenase type I (Worthington, Lakewood, NJ, USA). After digestion, tissue fragments were filtered with a cell strainer $(100 \mu \mathrm{m}$ Nylon, BD Falcon, Milan, Italy). Cells derived from human PAds and human embryonic kidney (HEK293) cells were routinely grown in DMEM medium, supplemented with $10 \% \mathrm{FBS}, 2 \mathrm{mM}$ L-glutamine and $1 \%$ penicillin/streptomycin (all from Gibco-Invitrogen, ThermoFischer Scientific) under standard culture conditions $\left(5 \% \mathrm{CO}_{2}, 37^{\circ} \mathrm{C}\right)$.

\section{CASR gene transfection and FLNA silencing}

HEK293 cells were plated in MW6 plates at a density of $10^{5}$ cells/well in complete medium. When cells reached

Published by Bioscientifica Ltd. 
70-90\% confluence, they were simultaneously silenced for FLNA, with predesigned small interfering RNA (siRNA) (Stealth RNAi HSS103734, Invitrogen), and transiently transfected with plasmid encoding for wild-type CASR (990R-CASR), obtained by site-directed mutagenesis as previously described (Terranegra et al.2010), or 990G CASR, kindly provided by Dr Jianxin $\mathrm{Hu}$ (NIH). Transfection, silencing and cotransfection were performed with 10, 5 and $12 \mu \mathrm{L}$ Lipofectamine 2000 (Invitrogen), respectively, $4 \mu \mathrm{g}$ CASR plasmid and $500 \mathrm{pmol}$ of FLNA siRNA in OptiMEM serum-free medium (Invitrogen) for each well. To obtain the best efficiency of FLNA silencing, three different human FLNA siRNAs were tested. Preliminary experiments to determine the optimal concentration of siRNA and the FLNA silencing kinetics were performed. As negative control in each experiment, medium GC duplex stealth RNAi negative control duplex human (control siRNA) was used as indicated by manufacture instructions (Invitrogen). The growth medium was changed to starvation medium (serum-free medium supplemented with $0.2 \%$ BSA and $1 \%$ penicillin/streptomycin) $24 \mathrm{~h}$ after cotransfection. Gene expression and activity were tested $72 \mathrm{~h}$ after transfection.

\section{Total and membrane CASR and FLNA protein quantifications}

HEK293 cells, plated in MW6 plates, were trypsinized, and the pellets were lysed with ice-cold lysis buffer $(150 \mathrm{mM} \mathrm{NaCl}, 10 \mathrm{mM}$ Tris-HCl pH 7.2, 0.1\% SDS, $1 \%$ Triton X-100, 1\% deoxycholate, $5 \mathrm{mM}$ EDTA, $1 \mathrm{mM}$ PMSF, $10 \mathrm{mM}$ benzamidine, $2 \mu \mathrm{g} / \mathrm{mL}$ leupeptin, $0.1 \mathrm{mM}$ Na-orthovanadate). The lysates were centrifuged and the supernatants were recollected to quantify proteins by BCA protein assay kit (Pierce). The membrane proteins extraction was performed with Mem-Per plus kit by manufacture instructions (Thermo Fisher Scientific, Life Technologies Italia). All samples $(10 \mu \mathrm{g}$ proteins/well) were denatured with loading dye buffer and $\beta$-mercaptoethanol for $10 \mathrm{~min}$ at $95^{\circ} \mathrm{C}$ to obtain proteins for FLNA and ERK analysis or with denaturing buffer: $7 \mathrm{M}$ urea, $2 \mathrm{M}$ thiourea, $65 \mathrm{mM}$ DTT, $5 \times$ Laemmli sample buffer (final concentration 2\% SDS) for $30 \mathrm{~min}$ at room temperature for the analysis of the CASR dimeric (250 kDa) and monomeric (130-150 kDa) receptor isoforms. Iodoacetamide $(130 \mathrm{mM})$ was added to block DTT for $30 \mathrm{~min}$ at room temperature. Proteins were separated by $8 \% \mathrm{w} / \mathrm{v}$ SDS-PAGE, and then electrotransferred to PVDF membrane. The blots were blocked in a blocking solution (5\% milk in TBST or
$5 \%$ BSA in TBST) and then incubated overnight at $4^{\circ} \mathrm{C}$ with different antibodies: 1:5000 dilution monoclonal CASR antibody (Affinity Bioreagents, Golden, CO, USA), 1:10,000 dilution monoclonal anti-GAPDH antibody (Abnova Corporation), 1:1000 dilution polyclonal anti- $\beta$-actin antibody (Sigma Chemicals) and 1:1000 dilution anti-Na/K-ATPase antibody (Cell Signaling), for $2 \mathrm{~h}$ at room temperature. The FLNA expression levels were assessed in each experiment with 1:5000 dilution monoclonal full-length FLNA antibody (Abnova Corporation). Membranes were incubated in the blocking solution with secondary horseradish peroxidase-coupled anti-mouse or anti-rabbit IgG (Jackson ImmunoResearch Laboratories). Specific protein bands were detected using SuperSignal West Pico enhanced chemiluminescence system (Pierce). Experiments were repeated at least thrice. The band intensities, corresponding to the levels of protein expression, were measured by ImageJ software.

\section{Phosphorylated ERK1/2 quantification}

Serum-starved transfected HEK293 cells were stimulated with increasing concentrations of calcium chloride $\left(\mathrm{CaCl}_{2} ; 0.5,1.0,3.0\right.$ and $\left.5.0 \mathrm{mM}\right)$ with or in the absence of the calcimimetic R568 $(0.01 \mu \mathrm{M}$; kindly provided by Amgen Inc.) for $10 \mathrm{~min}$ at $37^{\circ} \mathrm{C}$ in saline solution PSS ( $\mathrm{NaCl} 125 \mathrm{mM}, \mathrm{KCl} 4 \mathrm{mM}$, HEPES $20 \mathrm{mM}$, D-Glucose 0.1\%, $\left.\mathrm{NaH}_{2} \mathrm{PO}_{4} 0.8 \mathrm{mM}, \mathrm{MgCl}_{2} 1 \mathrm{mM}, \mathrm{pH} 7.45\right)$. Incubation was stopped by placing the cells on ice. The PSS was removed and the cells were treated with $50 \mu \mathrm{L}$ ice-cold lysis buffer as described previously, supplemented with complete phosphatase inhibitor cocktail (Roche Diagnostics Spa). Samples $(20 \mu \mathrm{g}$ proteins/well) were denatured with loading dye and $\beta$-mercaptoethanol for $10 \mathrm{~min}$ at $95^{\circ} \mathrm{C}$. Proteins were separated on $10 \% \mathrm{w} / \mathrm{v}$ SDS-PAGE and analysis of ERK1/2 activation was performed by western blot with 1:1000 and 1:2000 dilution polyclonal anti-p44/42 ERK and anti-phospho-p44/42 ERK antibodies, respectively (Cell Signaling Technology). Specific protein bands were detected by a chemiluminescent method as described previously for CASR and FLNA proteins quantification. Experiments were repeated at least thrice.

\section{Genotyping}

Genomic DNA was extracted from 74 frozen human PAds tissues samples using TRIzol reagent (Invitrogen) following manufacturer's instructions. CASR R990G SNP genotyping was performed by a specific TaqMan SNP

Published by Bioscientifica Ltd. 
genotyping assay (C_7504854_20, Life Technologies Ltd) with the Applied Biosystems 7500 Fast Real-Time PCR Systems. Amplification was performed in $8 \mu \mathrm{L}$ final volume with $20 \mathrm{ng}$ of genomic DNA at the following conditions: $95^{\circ} \mathrm{C}$ for $20 \mathrm{~s}$, and 40 cycles each of $95^{\circ} \mathrm{C}$ for $3 \mathrm{~s}$ and $60^{\circ} \mathrm{C}$ for 30 s. SNP variation was assessed by means of the allelic discrimination assay employing the Applied Biosystems Software Package SDS 2.1.

\section{PHPT patients}

We collected the clinical and biochemical data of the 74 patients with primary hyperparathyroidism (PHPT) (57 females, 17 males, age $59.7 \pm 14.2$ years), whose surgically removed PAds were analyzed. PHPT was diagnosed when hypercalcemia (serum calcium $>10.2 \mathrm{mg} / \mathrm{dL}$ and/or ionized calcium $>1.30 \mathrm{mmol} / \mathrm{L}$ ) and elevated or inappropriately normal serum PTH level occurred. Exclusion criteria were diagnosis of familial hypocalciuric hypercalcemia (detection of calcium-to-creatinine clearance ratio $>0.01$ following vitamin D deficiency correction (Marcocci et al. 2015)), previously established diagnosis of chronic kidney disease, hyperthyroidism, pregnancy, glucocorticoids, bisphosphonates, diuretics and calcimimetic treatments. All patients were Caucasians. Patients underwent clinical and laboratory evaluation, including: (1) personal and family medical history; (2) physical examination including arterial blood pressure, weight and height measurement; (3) fasting biochemical evaluation including total and ionized calcium, phosphate, intact PTH, 25hydroxyvitaminD3, creatinine; a 24-h urine collection was obtained from all patients for urinary calcium and phosphate excretion; and (4) imaging evaluation including lumbar and femoral dual-energy X-ray absorptiometry (DEXA), vertebral spine $\mathrm{X}$-ray and ultrasound kidney examination. Osteoporosis was diagnosed in 50\% and kidney stones in 30\% of PHPT patients. Biochemical and hormonal parameters were assayed by routine methods. All participants gave their informed consent after full explanation of the purpose and nature of all used procedures; the protocol study was approved by the local ethics committee.

\section{Statistical analysis}

Results are expressed as mean \pm standard error of the mean (s.e.M.) or median and range interquartile. Analysis of variance was performed by ANOVA or Wilcoxon rank-sum tests. Correlation between FLNA and CASR expression levels in PAds was analyzed by linear regression analysis. Differences between two groups were tested by Student's t-test or Mann-Whitney test. A $P$ value $<0.05$ was considered statistically significant.

\section{Results}

FLNA protein expression in human normal and tumor parathyroids

In normal parathyroid glands $(n=6)$, most epithelial parathyroid cells showed intense staining for full-length FLNA in the cytoplasm and at membrane level (Fig. 1, panel A, a). Endothelial cells lining the vessels showed intense staining for FLNA (arrows in Fig. 1, panel A, $\mathrm{a}, \mathrm{b}$ and $\mathrm{c}$ ) and were considered as internal positive controls. A pattern of staining similar to that in normal parathyroid glands was detected in sporadic parathyroid adenomas samples (PAds, $n=10$ ), though the amount of FLNA-expressing cells was variably reduced among the samples (Fig. 1, panel A, b and c) ranging from 50\% to $10 \%$ of tumor parathyroid epithelial cells. Remarkably, the FLNA-expressing cells were $<10 \%$ or absent in parathyroid carcinomas (PCas, $n=7$ ) (Fig. 1, panel A, d). Therefore, a subset of PAds and the most PCas showed a variable loss of FLNA-expressing cells (Fig. 1, panel B). By immunofluorescence on PAds-derived cultured single cells, full-length FLNA was detected at membrane level and in the cytoplasm of a subset of tumor parathyroid cells, where it co-localized with CASR with a membrane and peripheral cytoplasmic distribution (Fig. 1, panel C). Indeed, immunoblotting-fractioned proteins from HEK293 cells and PAds, using a primary antibody against the C-terminal calpain cleaved fragment of FLNA, detected a specific band of $100 \mathrm{kDa}$ in the nuclear protein fractions. An additional band of $270 \mathrm{kDa}$ corresponding to the full-length FLNA was also visualized in all samples (Fig. 1, panel D); the nuclear accumulation of full-length FLNA, though detected by IHC in some tumor cells (data not shown), may be related to the sensitivity of the immunoblotting on fractioned proteins.

\section{Effect of FLNA gene silencing on CASR expression levels}

The effect of FLNA loss on CASR expression was investigated in 990R-CASR-transiently transfected HEK293 cells silenced for FLNA by siRNA technique. As shown in Fig. 2, panel A, in HEK293 cells, 72-h FLNA silencing consistently decreased endogenous FLNA protein expression (about 70-80\%), compared to control siRNA transfected cells. The siRNA efficiency was not affected by cotransfection of the CASR plasmids (Fig. 2, panel A).

Published by Bioscientifica Ltd. 
A

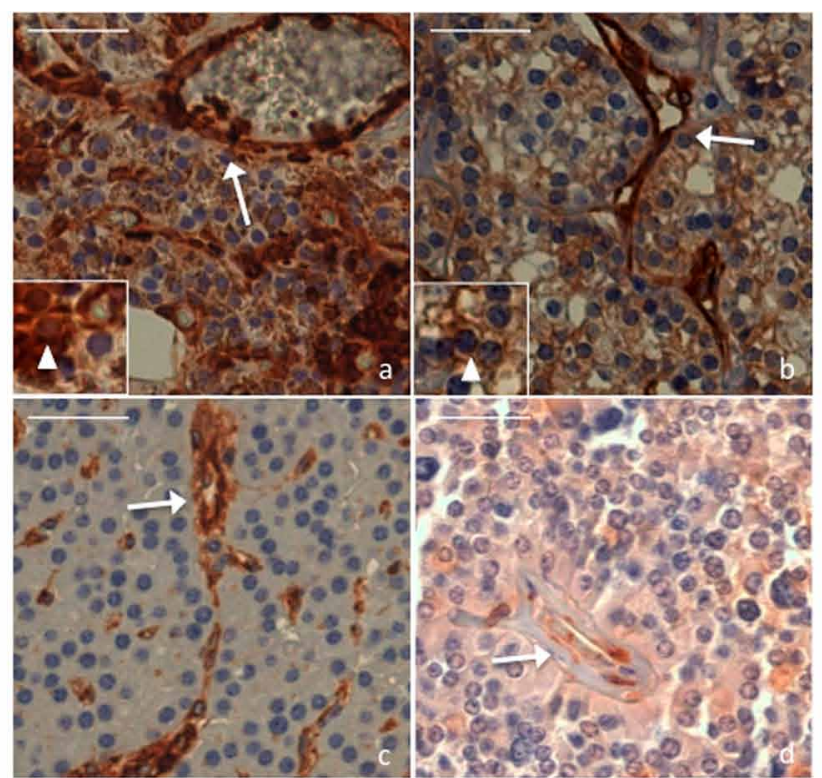

B

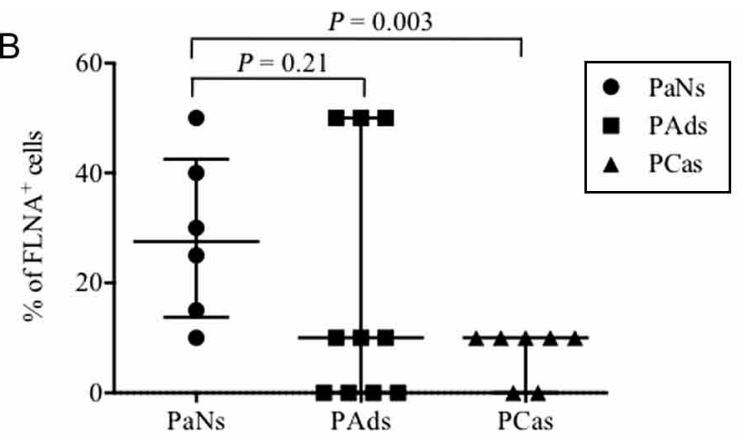

$\mathrm{D}$

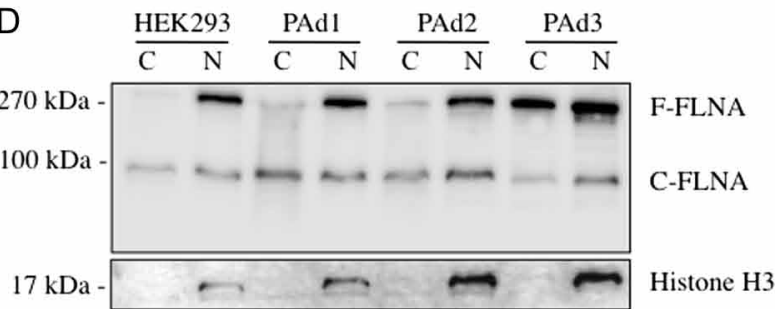

C
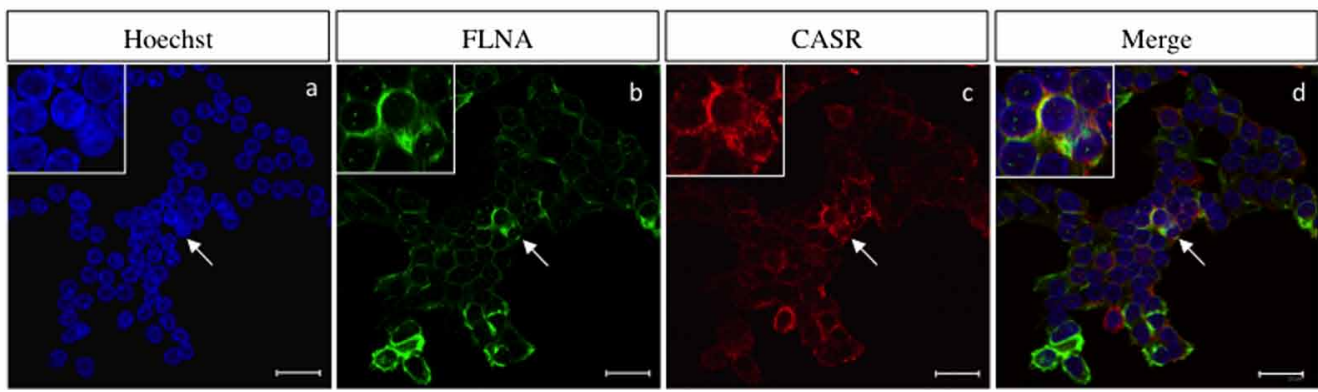

Figure 1

Filamin A protein expression in human normal parathyroid glands and parathyroid tumors. (A) Representative tissue sections analyzed by immunohistochemistry with specific anti-full-length FLNA antibody. (a) Intense staining in the cytoplasm and at membrane level in epithelial cells of normal parathyroid gland; white arrow indicates endothelial cells, considered as positive internal control; insert, magnification showing membrane and cytoplasmic specific staining for FLNA in a parathyroid cells (white arrowhead). (b) Proportion of FLNA-expressing cells (50\%) similar to normal glands in a sporadic PAds; insert, magnification showing FLNA-expressing cells (white arrowhead) besides negative or poor-expressing cells; white arrow indicates positive endothelial cells. (c) PAd section where FLNA staining involves only endothelial cells (white arrow). (d) PCa section negative for FLNA specific immunostaining; white arrow indicates positive endothelial cells. Scale bars represent $100 \mu \mathrm{m} ; \mathrm{a}, \mathrm{b}, \mathrm{c}$, and d, were imaged at 20x magnification; inserts were imaged at 40x magnification. (B) Proportions of full-length FLNA-expressing cells detected by immunohistochemistry in normal parathyroid glands (PaNs), in parathyroid adenomas (PAds) and in parathyroid carcinomas (PCas); medians and interquartile ranges are shown. (C) Confocal microscope immunofluorescent images of PAds-derived cultured single cells: (a) Hoechst nuclear staining; (b) FLNA-expressing (green) cells at membrane and cytoplasmic levels; (c) CASR-expressing (red) cells; (d) merged image showing that a small subset of cells co-expressing FLNA and CASR at high levels; inserts, magnification of the cell indicated by the white arrows. Scale bars represent $20 \mu \mathrm{m} ; \mathrm{a}, \mathrm{b}, \mathrm{c}$ and d were imaged at $100 \times$ magnification; inserts were imaged at $200 \times$ magnification. (D) Immunoblot with a specific antibody against the $100 \mathrm{kDa}$ calpain cleaved FLNA fragment (C-FLNA) on fractioned proteins from HEK293 cells and PAds; the antibody detects also faint bands of $270 \mathrm{kDa}$ in the nuclear protein fractions corresponding to the full-length FLNA (F-FLNA); histone H3 is used as control for the nuclear proteins; C, cytoplasmic; HEK293, HEK293 cell preparation; N, nuclear; PAd, parathyroid adenoma.

Loss of FLNA significantly reduced the total and membrane 990R-CASR protein levels (Fig. 2, panels B and C). Cotransfection of the 990R-CASR plasmid and control siRNA did not affect the 990R-CASR expression levels both in the total and in the membrane protein fractions, which were similar to those detected in HEK293 cells transfected with the 990R-CASR plasmid alone (Fig. 2, panels B and C).

\section{FLNA and CASR mRNA expression levels in PAds}

Loss of FLNA-induced CASR protein reduction might be due to reduced receptor stabilization with consequent increased degradation and/or by inhibition of CASR gene expression. The FLNA full-length and cleaved fragments can regulate gene expression directly or indirectly through interaction with a number of intracellular pathways (Savoy \& Ghosh 2013). We observed that FLNA silencing also reduced 
A Total protein extracts from HEK293 cells

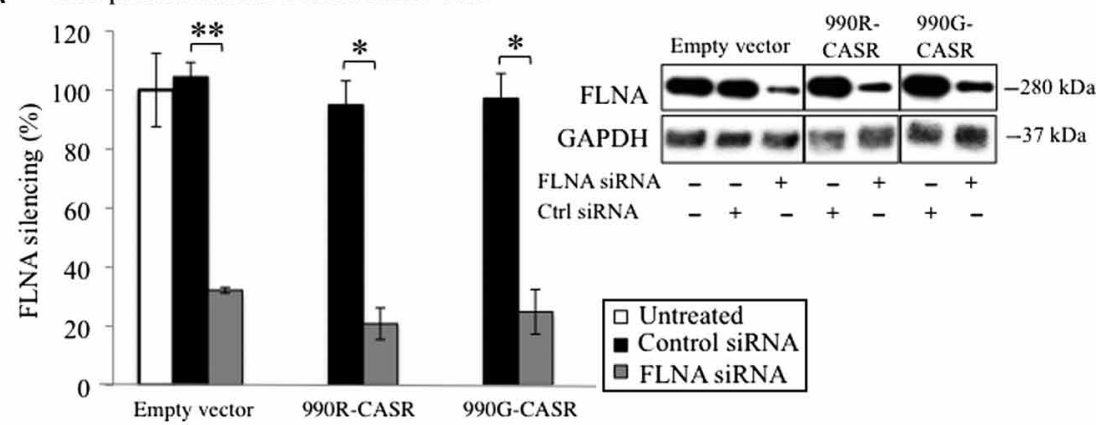

B Total protein extracts from HEK293 cells

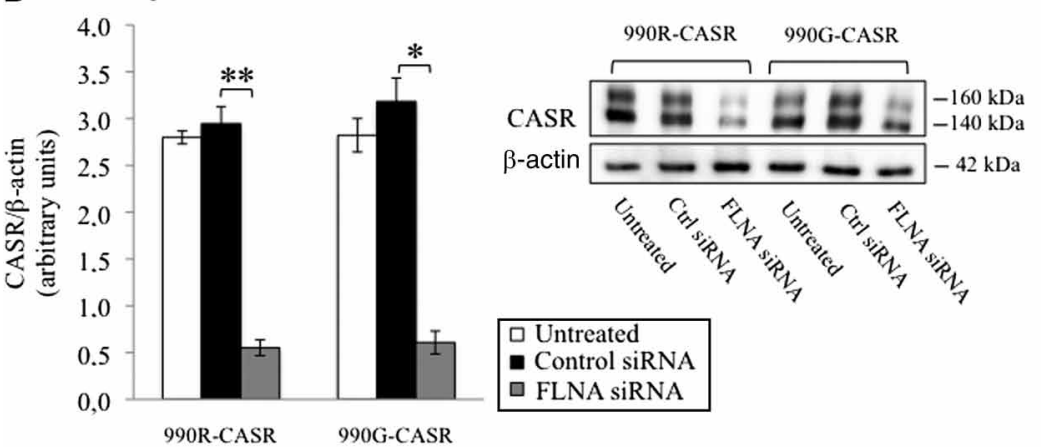

C Membrane protein extracts from HEK293 cells

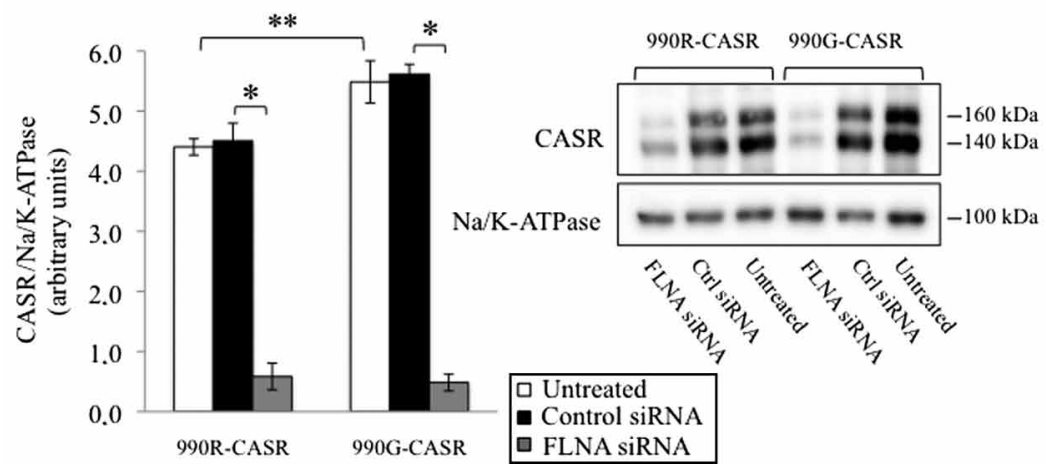

Figure 2

Effects of FLNA silencing in CASR-transfected HEK293 cells. Mean expression levels quantified by densitometry of the indicated proteins in every cell preparations (left diagrams); representative western blot of the experiments (on the right). (A) Endogenous FLNA silencing was efficient in HEK293 cells co-transfected with the empty vector, the 990R-CASR and the 990G-CASR; the representative western blot shows the full-length FLNA protein of $280 \mathrm{kDa}$; GAPDH was used as internal control. (B) Endogenous FLNA silencing induced a down-regulation of both 990R-CASR and 990G-CASR proteins in total protein extractions, while the FLNA control siRNA did not affect the CASR expression levels; the representative western blot shows the CASR monomeric isoforms of $140-160 \mathrm{kDa} ; \beta$-actin was used as internal control. (C) Endogenous FLNA silencing induced a down-regulation of both 990R-CASR and 990G-CASR proteins in membrane protein fractions, while the FLNA control siRNA did not affect the CASR expression levels; the representative western blot shows the CASR monomeric isoforms of $140-160 \mathrm{kDa}$; Na/K-ATPase was used as internal control. ${ }^{*} P<0.001$; ${ }^{*} P<0.05 ;$ Ctrl siRNA, control FLNA siRNA.
CASR mRNA levels in 990R-CASR-HEK293 cells (Fig. 3, panel A). HEK293 cells do not express endogenous CASR gene and protein and the 990R-CASR-HEK293 cell model was generated by transfecting a CASR plasmid lacking the endogenous regulatory region. Therefore, loss of FLNAinduced CASR inhibition could not be a direct nuclear effect.

We further investigated FLNA and CASR mRNA expression levels in tissue samples from 74 sporadic PAds surgically removed from patients with a clinical and hormonal diagnosis of PHPT. FLNA and CASR mRNA levels, reported as a ratio with GAPDH mRNA, were highly variable among PAds samples and CASR mRNA levels positively correlated with FLNA mRNA levels $\left(r^{2}=0.223, P<0.0001\right)$ (Fig. 3, panel B), suggesting a potential modulation of the CASR gene transcript by FLNA. Nonetheless, FLNA and CASR mRNA levels of PAds did not show any significant correlation with the PHPT severity (Table 1): FLNA and CASR mRNA levels of PAds associated with severe PHPT, defined as clinical diagnosis of kidney stones and/or osteoporosis and/or osteoporotic fractures and/or serum calcium $>1 \mathrm{mg} / \mathrm{dL}$ above the upper limit of the normal range, were similar to those detected in PAds associated with mild PHPT (Marcocci et al. 2015).

However, CASR and FLNA protein expression levels, detected by western blot analysis, did not show significant http://jme.endocrinology-journals.org DOI: 10.1530/JME-16-0184
(C) 2017 Society for Endocrinology Printed in Great Britain 
A
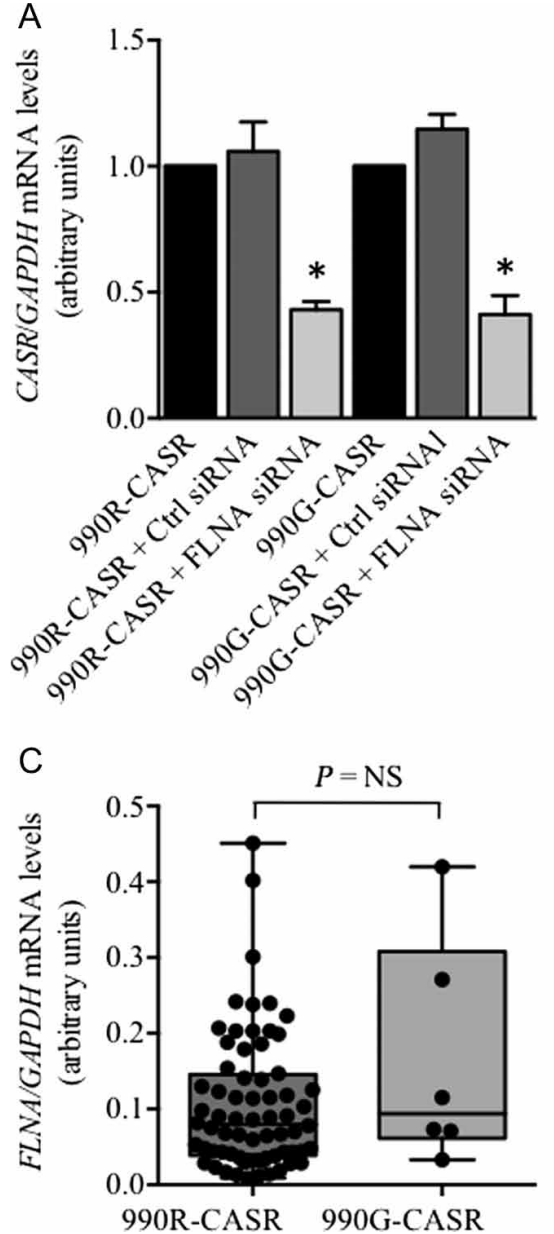

B
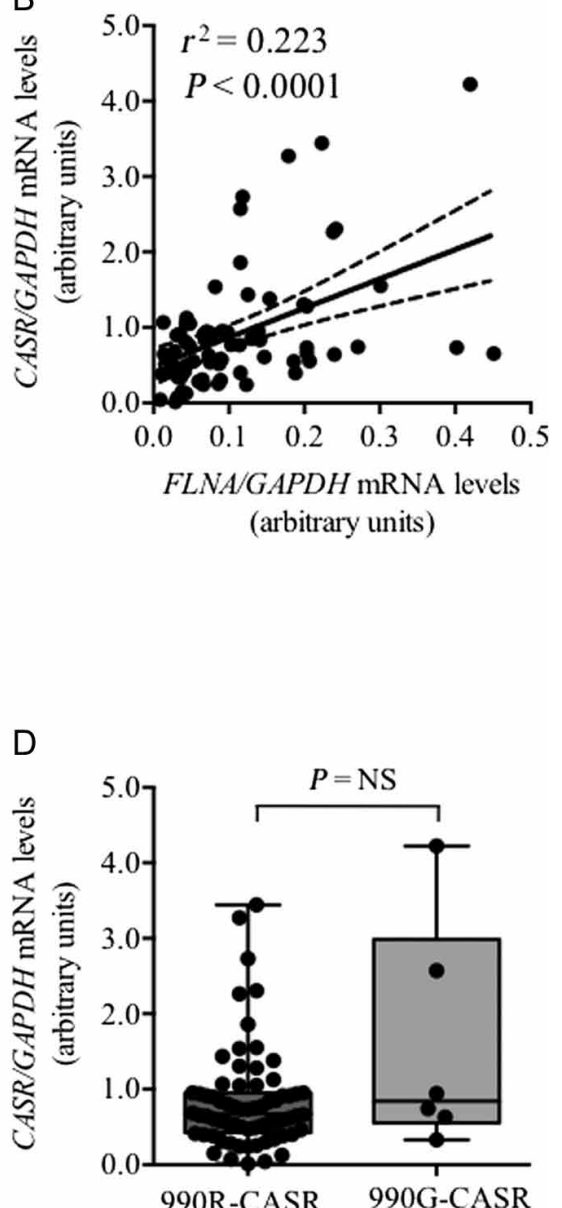

Figure 3

FLNA and CASR mRNA levels in CASR-transfected HEK-293 cells and sporadic parathyroid adenomas. (A) Effect of FLNA silencing on CASR mRNA expression levels in 990R-CASR-HEK293 and 990G-CASR-HEK293 cells; columns represent means and SEMs; $* P<0.05$. (B) Tumor FLNA expression levels positively correlated with CASR expression levels in a series of 74 sporadic parathyroid adenomas; the best-fit line (continuous line) and $95 \%$ confidence bands (dashed lines) are shown. (C) Boxes and whiskers representing expression levels of FLNA in tumors harboring the 990R allele (990R-CASR) compared with those detected in tumors harboring the 990G allele of the CASR gene (990G-CASR); horizontal line in the boxes represent the median values, whiskers represent minimum to maximum values, black dots represent single samples. (D) Boxes and whiskers representing expression levels of CASR in tumors harboring the $990 \mathrm{R}$ allele (990R-CASR) compared with those detected in tumors harboring the $990 \mathrm{G}$ allele of the CASR gene (990G-CASR); horizontal line in the boxes represented the median values, whiskers represented minimum to maximum values, black dots represent single sample. correlation (Fig. 3A and B); though there were tumors (PAd1 and PAd6) with low FLNA levels and low CASR levels or high FLNA levels and high CASR levels (PAd2), other tumors (PAd3 and PAd4) had low FLNA levels and consistent CASR expression levels or high FLNA levels and low CASR levels (PAd5).

\section{Effect of the 990G CASR allele on FLNA and CASR mRNA expression}

Genotyping for the CASR 990 single nucleotide variants of the PAds samples identified 68 tumors harboring the major allele 990R and 6 tumors harboring the minor allele $990 \mathrm{G}$ of the CASR gene. PAds harboring the $990 \mathrm{G}$

Table 1 Comparisons of biochemical parameters and tumor gene expressions between severe and mild PHPT patients.

\begin{tabular}{|c|c|c|}
\hline & Severe PHPT & Mild PHPT \\
\hline No. patients & 52 & 22 \\
\hline Serum ionized calcium (mmol/L)a & $1.57(1.47-1.67)$ & $1.46(1.36-1.53)$ \\
\hline Serum alb-corr calcium (mg/dL) & $11.6(11.0-12.3)$ & $10.9(10.7-11.2)$ \\
\hline Serum iPTH (pg/mL) & $201.5(130.0-319.0)$ & $125.0(104.0-254.4)$ \\
\hline Serum phosphate (mg/dL) & $2.25(1.88-2.6)$ & $2.40(2.13-2.73)$ \\
\hline Kidney stones (\%) & 41.7 & 0 \\
\hline Osteoporosis (\%) & 70.8 & 0 \\
\hline Mean Qty FLNA & $0.07(0.04-0.19)$ & $0.08(0.04-0.12)$ \\
\hline Mean Qty CASR & $0.74(0.41-1.08)$ & $0.84(0.48-1.46)$ \\
\hline
\end{tabular}

Criteria for PHPT severity are according Marcocci et al. (2015).

$\mathrm{a} P=0.0046 ; \mathrm{b} P=0.0003$.

alb-corr, albumin-corrected calcium (normal value: 8.2-10.4 mg/dL); CASR, calcium sensing receptor; FLNA, filamin A; iPTH, intact parathormone; Qty, gene expression relative quantity.

http://jme.endocrinology-journals.org DOI: 10.1530/JME-16-0184
(C) 2017 Society for Endocrinology Printed in Great Britain
Published by Bioscientifica Ltd 
CASR variant were associated with mean serum intact PTH levels lower than those in PAds harboring the 990R variant $(171.0 \pm 24.9$ vs $328.1 \pm 44.0 \mathrm{pg} / \mathrm{mL}, P=0.003)$, whereas mean serum albumin-corrected calcium levels were similar $(11.3 \pm 0.4$ vs $11.6 \pm 0.1 \mathrm{mg} / \mathrm{dL} ; P=0.76)$. No significant difference could be detected in the PAds harboring the 990R compared with PAds harboring the 990G variants in the median expression levels of the FLNA (median, range interquartile: $0.08,0.04-0.15$ vs 0.09, 0.06-0.31; $P=0.33$; Fig. 4, panel C) and CASR genes (median, range interquartile: $0.68,0.43-0.96$ vs 0.84 , 0.56-2.98; $P=0.14$; Fig. 4, panel D).

\section{Effect of FLNA gene silencing on the CASR-stimulated p44/42 ERK phosphorylation}

To evaluate the effect of the loss of FLNA expression on the CASR-activated signaling, we measured the levels of phosphorylated p44/42 ERK in 990R-CASR cells after FLNA silencing. After 72-h incubation with FLNA siRNA or control siRNA, 990R-CASR was activated by increasing extracellular calcium concentrations $\left(\left[\mathrm{Ca}^{2+}\right]_{\mathrm{o}}\right)$, from 0.5 to $1.0,3.0$ and $5.0 \mathrm{mM}$, as shown in Fig. 5, panel A. Loss of FLNA expression in 990R-CASR HEK293 cells did not significantly alter ERK phosphorylation levels at 0.5 and $1.0 \mathrm{mM}\left[\mathrm{Ca}^{2+}\right]_{\mathrm{o}}$, whereas at 3.0 and $5.0 \mathrm{mM}\left[\mathrm{Ca}^{2+}\right]_{\mathrm{o}}$, it significantly decreased the 990R-CASR activationinduced phospho-ERK levels compared to those detected in 990R-CASR HEK293 cells transfected with the control siRNA $(0.75 \pm 0.06$ vs $0.92 \pm 0.08 ; P=0.006$ at $3.0 \mathrm{mM}$ $\left[\mathrm{Ca}^{2+}\right]_{\mathrm{o}} ; 0.71 \pm 0.24$ vs $1.21 \pm 0.38 ; P=0.02$ at $5.0 \mathrm{mM}$ $\left[\mathrm{Ca}^{2+}\right]_{\mathrm{o}}$ ) (Fig. 5, panel A). The incubation with the potent calcimimetic R568 $0.01 \mu \mathrm{M}$ blunted the effect of FLNA loss on the 990R-CASR-induced phosphorylation of ERK at any $\left[\mathrm{Ca}^{2+}\right]_{\mathrm{o}}$ (Fig. 5, panel B).

\section{Effects of the 990G CASR allele on FLNA-modulated CASR protein expression and CASR-mediated ERK phosphorylation}

In HEK293 cells co-transfected with either 990R-CASR and 990G-CASR and siRNA control, we observed that the amount of 990G-CASR in the membrane protein fraction was significantly higher than that of 990R-CASR $(5.3 \pm 0.25$ vs $4.4 \pm 0.1, P=0.03)$ (Fig. 2, panel C). Loss of FLNA in 990G-CASR-HEK293 cells reduced the total and membrane 990G-CASR protein levels at an extent similar to that observed in the 990R-CASR transfected HEK293 cells (Fig. 2, panels B and C). In HEK293 cells
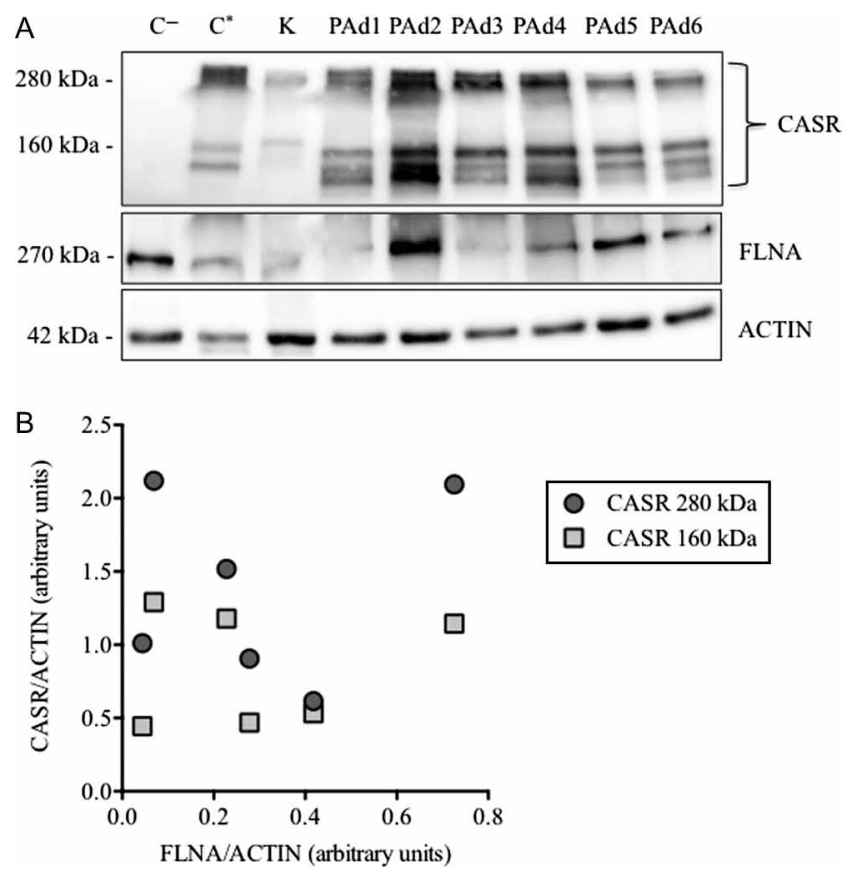

Figure 4

FLNA and CASR expression by western blot analysis in parathyroid adenomas. (A) The three different bands corresponding to the monomeric immature glycosylated $(140 \mathrm{kDa})$, the mature glycosylated $(160 \mathrm{kDa})$ and the dimeric $(280 \mathrm{kDa})$ forms of CASR were visualized; the band at $270 \mathrm{kDa}$ corresponding to full-length FLNA was detected; actin was used as internal control; C+, HEK293 stably transfected with CASR; C-, HEK293 cells; K, human normal kidney; PAd, parathyroid adenoma. (B) Lack of correlation between CASR and FLNA protein expression levels detected by western blot in parathyroid adenomas. The band intensities, corresponding to the levels of protein expression, were measured by Image J software.

transfected with the 990G-CASR and endogenous FLNA, 990G-CASR activation by increasing $\left[\mathrm{Ca}^{2+}\right]_{0}$-stimulated ERK phosphorylation at higher levels than that observed in 990R-CASR-expressing cells, which gained the statistical significance at $5.0 \mathrm{mM}\left[\mathrm{Ca}^{2+}\right]_{\mathrm{o}}(2.80 \pm 0.68$ vs $1.21 \pm 0.38 ; P=0.02$ ), in agreement with previous report (Terranegra et al. 2010) (Fig. 5, panel A). Loss of FLNA by treatment with siRNA reduced 990G-CASR-induced phospho-ERK levels with a significant difference at $5.0 \mathrm{mM}$ $\left[\mathrm{Ca}^{2+}\right]_{\circ}(1.33 \pm 0.43$ vs $2.80 \pm 0.68 ; P=0.04)$ (Fig. 5 , panel A). Finally, treatment of 990G-CASR-HEK293 cells with $0.01 \mu \mathrm{M}$ R568 blunted the effect of FLNA loss as observed in 990R-CASR-expressing cells, though in the presence of FLNA, 990G-CASR-expressing cells showed higher $\left[\mathrm{Ca}^{2+}\right]_{0}{ }^{-}$ induced phospho-ERK levels than 990R-CASR-expressing cells reaching statistical significance at $3.0 \mathrm{mM}$ and $5.0 \mathrm{mM}\left[\mathrm{Ca}^{2+}\right]_{\mathrm{o}}(3.10 \pm 0.34$ vs $1.94 \pm 0.38$ and $3.13 \pm 0.20$ vs $2.48 \pm 0.03$, respectively; $P=0.04$ ) (Fig. 5 , panel B), in agreement with previous report (Terranegra et al. 2010). http://jme.endocrinology-journals.org DOI: 10.1530/JME-16-0184
() 2017 Society for Endocrinology Printed in Great Britain
Published by Bioscientifica Ltd 

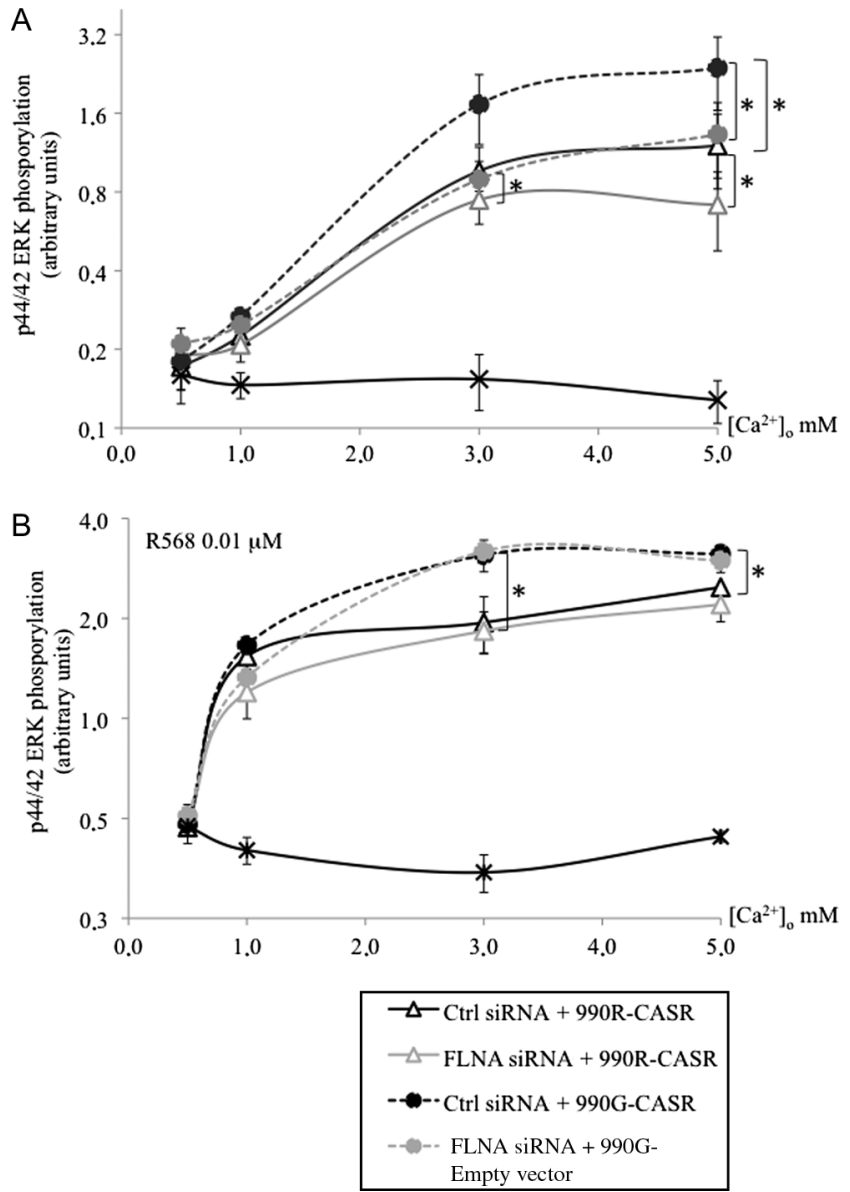

Figure 5

Effect of FLNA silencing in CASR-activated ERK signaling in CASRtransfected HEK293 cells. (A) In HEK293 cells transfected with the 990G-CASR and endogenous FLNA (black dashed line), 990G-CASR activation by increasing $\left[\mathrm{Ca}^{2+}\right]_{0}$ stimulated ERK phosphorylation at higher levels than that observed in 990R-CASR-expressing cells (black continuous line), reaching the statistical significance at $5.0 \mathrm{mM}\left[\mathrm{Ca}^{2+}\right]_{0}$. Loss of FLNA by treatment with siRNA reduced 990G-CASR-induced phospho-ERK levels (grey dashed line) with a significant difference at $5.0 \mathrm{mM}\left[\mathrm{Ca}^{2+}\right]_{0} .{ }^{\S \varsigma} \mathrm{Ctrl}$ siRNA + 990G-CASR vs Ctrl siRNA + 990R-CASR, $P=0.02$; ${ }^{\mathrm{C}} \mathrm{Ctrl}$ siRNA + 990G-CASR vs FLNA siRNA + 990G-CASR, $P=0.04$; ${ }^{\mathrm{C}} \mathrm{tr}$ siRNA+990R-CASR vs FLNA siRNA+990R-CASR, $P=0.02$. (B) Treatment of 990G-CASR-expressing HEK293 cells with increasing $\left[\mathrm{Ca}^{2+}\right]_{\text {。 }}$ concentrations in presence of $0.01 \mu \mathrm{M}$ R568 overrode the FLNA loss as observed in 990R-CASR-expressing cells (grey continuous line), though, in presence of FLNA, 990G-CASR-expressing cells (black dashed line) showed higher $\left[\mathrm{Ca}^{2+}\right]_{0}$-induced phospho-ERK levels than 990R-CASR-expressing cells (black continuous line) reaching statistically significance at $5.0 \mathrm{mM}\left[\mathrm{Ca}^{2+}\right]_{0}$. p44/42 ERK phosphorylation levels are reported on logarithmic scale; ${ }^{*}$ Ctrl siRNA+ 990G-CASR vs Ctrl siRNA + 990R-CASR, $P=0.02$.

\section{Discussion}

In the present study, the scaffold protein filamin A (FLNA) was firstly shown to be downregulated in human parathyroid tumors. Most cells in normal parathyroid glands expressed full-length FLNA protein in cytoplasm and in association with membrane, whereas FLNA-expressing cells were variably reduced in parathyroid adenomas with tumor samples displaying an immunostaining pattern similar to that in normal glands and samples with a proportion of FLNA-expressing cells less than $10 \%$. FLNA-expressing cells were definitely reduced in all the parathyroid carcinomas samples. Loss of FLNA expression has been reported in prolactin-secreting pituitary tumors (Peverelli et al. 2012), where it is related to dopamine resistance, at variance with the increased expression detected in a variety of human cancers. The role of FLNA in tumorigenesis is complex and related to its subcellular localization: as scaffold protein, FLNA interacts with receptors localized in membranes; as cytoplasmic protein, FLNA functions in various growth signaling pathways, such as vascular endothelial growth factor, R-Ras and integrin signaling; as nuclear active cleaved fragment, it interacts with transcription factors and nuclear receptors (Savoy \& Ghosh 2013). In human parathyroid tumor cells, full-length FLNA was localized in membrane and in cytoplasm, similar to what was reported in bovine parathyroid cells (Hjälm et al. 2001); in addition, cleaved FLNA fragment could be detected in the nuclear protein fractions, suggesting FLNA potential involvement in multiple regulatory pathways in parathyroid tumor cells.

Parathyroid tumors are characterized by extracellular calcium insensitivity (Corbetta et al. 2000) and loss of CASR expression: compared with normal parathyroid glands, both CASR mRNA and protein are downregulated in parathyroid adenomas (Yano et al. 2003, Kawata et al. 2006), carcinomas (Haven et al. 2004, Wittenveen et al. 2011) and primary and secondary hyperplasia (MartinSalvago et al. 2003, Latus et al. 2013, Varshney et al. 2013a). CASR gene mutations have been rarely identified in sporadic parathyroid tumors (Guarnieri et al. 2010, Frank-Raue et al. 2011) and CASR gene deregulation is not sustained by promoter hypermethylation (Varshney et al. $2013 b$ ). Therefore, alternative mechanisms might induce CASR mRNA and protein downregulation in parathyroid tumor cells. It has been reported in HEK293 cells stably transfected with CASR that FLNA interaction with CASR carboxyl-terminal tail (Awata et al. 2001) is required for CASR stabilization through attenuation of its degradation (Zhang \& Breitwieser 2005). We tested the hypothesis that downregulation of CASR expression might be related to loss of FLNA in parathyroid tumors. We performed in vitro studies to investigate the effect of FLNA loss on CASR expression levels. Experiments were realized in HEK293 cells transiently transfected with 990R-CASR because

Published by Bioscientifica Ltd. 
lack of suitable human parathyroid cells; a robust cell system has been developed, where unspecific effects of CASR plasmids and FLNA siRNA cotransfection were ruled out. Loss of FLNA significantly reduced the 990R-CASR expression levels both in the total protein pools and in the membrane protein fractions, suggesting an involvement of FLNA in stabilization of 990R-CASR proteins in HEK293 cells. Indeed, loss of FLNA also reduced CASR mRNA levels, suggesting that FLNA might be active on CASR gene regulation, likely at post-transcriptional level (Savoy et al. 2015). In parathyroid adenomas, FLNA gene expression levels positively correlated with CASR gene expression levels, suggesting a FLNA-mediated modulation of CASR gene transcription; this hypothesis is further supported by the detection in the parathyroid adenomas nuclear protein fractions of cleaved FLNA fragments accumulation, which has been demonstrated to directly regulate gene transcription (Savoy \& Ghosh 2013). FLNA and/or CASR mRNA levels did not correlate with PHPT severity, suggesting that expression of these molecules is not a major determinant of the clinical phenotype associated with parathyroid tumors. Indeed, FLNA and CASR protein expression levels in parathyroid adenomas showed different patterns ranging from tumors with either low or high FLNA and CASR expression levels to tumors with discordant FLNA and CASR expression, in line with the wide range of reduced sensitivity to extracellular calcium characterizing the parathyroid tumors.

We further tested the hypothesis that FLNA is involved in the regulation of the CASR-mediated ERK activation and, firstly, evaluated the effect of the CASR agonist R568 when FLNA was reduced. FLNA interaction with CASR facilitates ERK phosphorylation (Zhang \& Breitwieser 2005) and CASR activation increases ERK phosphorylation in human normal and tumor parathyroid cells (Corbetta et al. 2002). In line with the previous report (Zhang \& Breitwieser 2005), in HEK293 cells transiently transfected with 990R-CASR, FLNA gene silencing reduced the $\left[\mathrm{Ca}^{2+}\right]_{0}$-induced ERK phosphorylation. Treatment with R568 blunted the effect of FLNA loss, consistent with the stabilizing effect of R568 on CASR membrane expression demonstrated in previous study (Miedlich et al. 2004, Huang \& Breitwieser 2007).

FLNA interacts with the CASR carboxyl-terminal tail at the domain between 972 and 997 amino acid residues (Awata et al. 2001, Hjalm et al. 2001). In this region, single nucleotide polymorphic variants have been identified and extensively investigated for the association with phenotype (Cetani et al. 2002, Mingione et al. 2015,
Vezzoli et al. 2015) and with the sensitivity to CASR agonist treatment in PHPT cohorts (Vezzoli et al. 2015). Just inside the FLNA binding region, a non-conservative CASR polymorphism, Arg990Gly (R990G), induces a gain of function in the receptor activity (Vezzoli et al. 2002, Scillitani et al. 2004, Corbetta et al. 2006). We investigated whether $990 \mathrm{G}$ allele affects the interaction of CASR C-terminus with FLNA testing the effect of FLNA loss on CASR-induced ERK phosphorylation in HEK293 cells transfected with 990G-CASR. Similar to what was observed with 990R-CASR, FLNA loss reduced 990G-CASR mRNA in 990G-CASR transfected cells. Parathyroid tumors harboring the 990G-CASR variant do not show significant differences in FLNA and CASR mRNA expression levels compared with tumors harboring the more frequent 990R-CASR variant. Loss of FLNA also reduced 990G-CASR protein levels in both total and membrane protein fractions, though in the presence of endogenous FLNA, expression of 990G-CASR in cell membrane was slightly higher than that of the 990R-CASR. Moreover, analyzing the effect of FLNA loss on 990G-CASR- and 990R-CASRinduced ERK phosphorylation, three conditions characterized by increasing sensitivity of CASR-mediated ERK activation could be identified: the less sensitive condition was determined by loss of FLNA associated with the 990R allele, whereas the most sensitive condition was provided by co-expression of FLNA and 990G allele. The conditions characterized by loss of FLNA associated with the 990G allele, and conserved FLNA associated with the 990R allele, displayed a variable reduced sensitivity. Nonetheless, as observed with 990R-CASR, R568 treatment was efficient in rescuing 990G-CASR sensitivity to $\left[\mathrm{Ca}^{2+}\right]_{0}$ in the absence of FLNA.

In conclusion, FLNA is variably downregulated in parathyroid tumors both at mRNA and protein levels. Therefore, parathyroid tumor cells are characterized by receptor and post-receptor defects, namely loss of CASR (Martin-Salvago et al. 2003, Yano et al. 2003, Haven et al. 2004, Kawata et al. 2006, Wittenween et al. 2011, Latus et al. 2013, Varshney et al. 2013a), Gq/11 protein (Corbetta et al. 2000) and FLNA. Data about loss of FLNA in 990R-CASR-transfected HEK293 cells confirmed previously reported results: reduction of CASR protein and of CASR-induced ERK phosphorylation. We further extended the investigation to the FLNA effect on CASR mRNA expression, finding that it is affected and therefore suggesting an additional FLNA-related deregulation, also supported by cleaved FLNA nuclear localization. Though the 990G allele was associated with increased http://jme.endocrinology-journals.org DOI: 10.1530/JME-16-0184
() 2017 Society for Endocrinology Printed in Great Britain
Published by Bioscientifica Ltd 
sensitivity to $\left[\mathrm{Ca}^{2+}\right]_{0}$, FLNA is required for receptor protein expression and ERK signaling activation. Treatment with R568 agonist is effective in the presence of different CASR and FLNA deregulated conditions.

Admittedly, our conclusions were limited by the fact that functional experiments were performed in HEK293 cells and could not be replicated in human normal or tumor parathyroid cells. It should also be considered that FLNA has been reported to interact with over 90 proteins, which indicates the numerous pathways that FLNA can affect (Stossel et al. 2001). Therefore, in parathyroid tumors with loss of FLNA, intracellular pathways other than ERK signaling might be impaired and contribute to the tumor phenotype.

\section{Declaration of interest}

The authors declare that they have no competing interests, with the exception of Laura Soldati who received funding from Amgen, USA.

\section{Funding}

The study was supported by Amgen, USA, IRCCS Policlinico San Donato and IRCCS Istituto Ortopedico Galeazzi Ricerca Corrente (L4080) funds.

\section{Authors' contribution statement}

M A carried out the experiments in HEK293 cells and CASR genotyping; V C performed immunofluorescence on PAds-derived cells; $F \mathrm{~S}$ and $\mathrm{V} V$ carried out immunhistochemistry for FLNA on human parathyroid sections; G V performed RNA extraction from human parathyroid tumors and real-time PCR gene quantification; S A collected clinical data from PHPT patients; V $L, B G$ and $B E$ collected fresh parathyroid tumor biopsies during surgery for PHPT; T A conceived experimental design in HEK293 cells and supervised M $A ; V G$ revised data on CASR genotyping; $S L$ and $S C$ conceived the project, collected and reviewed experimental data, discussed the results and wrote the manuscript. All authors read and approved the final manuscript.

\section{References}

Awata H, Huang C, Handlogten ME \& Miller RT 2001 Interaction of the calcium-sensing receptor and filamin, a potential scaffolding protein. Journal of Biological Chemistry 276 34871-34879. (doi:10.1074/jbc. M100775200)

Bondeson L, Grimelius L, De Lellis RA, Lloyd R, Akerstrom G, Larsson C, Arnold A, Eng C, Shane E \& Bilezikian JP 2004 Parathyroid carcinoma. In Pathology and Genetics. Tumors of Endocrine Organs. WHO Classification of Tumors, pp 128-132. Eds RA DeLelli, RV Lloyd, PU Heltz \& C Eng. Lyon, France: IARC Press.

Breitwieser GE 2013 The calcium sensing receptor life cycle: trafficking, cell surface expression, and degradation. Best Practice and Research Clinical Endocrinology and Metabolism 27 303-313. (doi:10.1016/j. beem.2013.03.003)

Breitwieser GE \& Gama L 2001 Calcium-sensing receptor activation induces intracellular calcium oscillations. American Journal of Physiology: Cell Physiology 280 C1412-C1421.
Cetani F, Borsari S, Vignali E, Pardi E, Picone A, Cianferotti L, Rossi G, Miccoli P, Pinchera A \& Marcocci C 2002 Calcium-sensing receptor gene polymorphisms in primary hyperparathyroidism. Journal of Endocrinological Investigation 25 614-619. (doi:10.1007/BF03345085)

Chakravarti B, Chattopadhyay N \& Brown EM 2012 Signaling through the extracellular calcium-sensing receptor. Advances in Experimental Medicine and Biology 740 103-142. (doi:10.1007/978-94-007-28882_5)

Conigrave AD \& Ward DT 2013 Calcium-sensing receptor (CaSR): pharmacological properties and signaling pathways. Best Practice and Research: Clinical Endocrinology and Metabolism 27 315-331. (doi:10.1016/j.beem.2013.05.010)

Corbetta S, Mantovani G, Lania A, Borgato S, Vicentini L, Beretta E, Faglia G, Di Blasio AM \& Spada A 2000 Calcium-sensing receptor expression and signalling in human parathyroid adenomas and primary hyperplasia. Clinical Endocrinology 52 339-348. (doi:10.1046/ j.1365-2265.2000.00933.x)

Corbetta S, Lania A, Filopanti M, Vicentini L, Ballaré E \& Spada A 2002 Mitogen-activated protein kinase cascade in human normal and tumoral parathyroid cells. Journal of Clinical Endocrinology and Metabolism 87 2201-2205. (doi:10.1210/jcem.87.5.8492)

Corbetta S, Eller-Vainicher C, Filopanti M, Saeli P, Vezzoli G, Arcidiacono T, Loli P, Syren ML, Soldati L, Beck-Peccoz P, et al. 2006 R990G polymorphism of the calcium-sensing receptor and renal calcium excretion in patients with primary hyperparathyroidism. European Journal of Endocrinology 155 687-692. (doi:10.1530/ eje.1.02286)

Frank-Raue K, Leidig-Bruckner G, Haag C, Schulze E, Lorenz A, SchmitzWinnenthal H \& Raue F 2011 Inactivating calcium-sensing receptor mutations in patients with primary hyperparathyroidism. Clinical Endocrinology 75 50-55. (doi:10.1111/j.1365-2265.2011.04059.x)

Guarnieri V, Canaff L, Yun FH, Scillitani A, Battista C, Muscarella LA, Wong BY, Notarangelo A, D'Agruma L, Sacco M, et al. 2010 Calciumsensing receptor (CASR) mutations in hypercalcemic states: studies from a single endocrine clinic over three years. Journal of Clinical Endocrinology and Metabolism 95 1819-1829. (doi:10.1210/jc.20082430)

Haven CJ, Van Puijenbroek M, Karperien M, Fleuren GJ \& Morreau H 2004 Differential expression of the calcium sensing receptor and combined loss of chromosomes $1 \mathrm{q}$ and $11 \mathrm{q}$ in parathyroid carcinoma. Journal of Pathology 202 86-94. (doi:10.1002/path.1489)

Huang Y \& Breitwieser GE 2007 Rescue of calcium-sensing receptor mutants by allosteric modulators reveals a conformational checkpoint in receptor biogenesis. Journal of Biological Chemistry 282 9517-9525. (doi:10.1074/jbc.M609045200)

Hjalm G, MacLeod RJ, Kifor O, Chattopadhyay N \& Brown EM 2001 Filamin-A binds to the carboxyl-terminal tail of the calcium-sensing receptor, an interaction that participates in CaR-mediated activation of mitogen-activated protein kinase. Journal of Biological Chemistry 276 34880-34887. (doi:10.1074/jbc.M100784200)

Kawata T, Imanishi Y, Kobayashi K, Onoda N, Okuno S, Takemoto Y, Komo T, Tahara H, Wada M, Nagano N, et al. 2006 Direct in vitro evidence of the suppressive effect of cinacalcet $\mathrm{HCl}$ on parathyroid hormone secretion in human parathyroid cells with pathologically reduced calcium-sensing receptor levels. Journal of Bone and Mineral Metabolism 24 300-306. (doi:10.1007/s00774-006-0687-y)

Lania A, Mantovani G, Ferrero S, Pellegrini C, Bondioni S, Peverelli E, Braidotti P, Locatelli M, Zavanone ML, Ferrante E, et al. 2004 Proliferation of transformed somatotroph cells related to low or absent expression of protein kinase A regulatory subunit $1 \mathrm{~A}$ protein. Cancer Research 64 9193-9198. (doi:10.1158/0008-5472.CAN-041847)

Latus J, Lehmann R, Roesel M, Fritz P, Braun N, Ulmer C, Steurer W, Biegger D, Ott G, Dippon J, et al. 2013 Involvement of $\alpha$-klotho, fibroblast growth factor-, vitamin D- and calcium-sensing receptor in http://jme.endocrinology-journals.org

DOI: 10.1530/JME-16-0184
() 2017 Society for Endocrinology Printed in Great Britain
Published by Bioscientifica Ltd 
53 patients with primary hyperparathyroidism. Endocrine $\mathbf{4 4}$ 255-263. (doi:10.1007/s12020-013-9881-6)

Lian G, Lu J, Hu J, Zhang J, Cross SH, Ferland RJ \& Sheen VL 2012 Filamin A regulates neural progenitor proliferation and cortical size through Wee-1-dependent Cdk1 phosphorylation. Journal of Neuroscience 32 7672-7684. (doi:10.1523/JNEUROSCI.0894-12.2012)

Marcocci C, Brandi ML, Scillitani A, Corbetta S, Faggiano A, Gianotti L, Migliaccio S \& Minisola S 2015 Italian Society of Endocrinology Consensus Statement: definition, evaluation and management of patients with mild primary hyperparathyroidism. Journal of Endocrinological Investigation 38 577-593. (doi:10.1007/s40618-0150261-3)

Martin-Salvago M, Villar-Rodriguez JL, Palma-Alvarez A, Beato-Moreno A \& Galera-Davidson H 2003 Decreased expression of calcium receptor in parathyroid tissue in patients with hyperparathyroidism secondary to chronic renal failure. Endocrine Pathology 14 61-70. (doi:10.1385/EP:14:1:61)

Miedlich SU, Gama L, Seuwen K, Wolf RM \& Breitwieser GE 2004 Homology modeling of the transmembrane domain of the human calcium sensing receptor and localization of an allosteric binding site. Journal of Biological Chemistry 279 7254-7263. (doi:10.1074/jbc. M307191200)

Mingione A, Verdelli C, Terranegra A, Soldati L \& Corbetta S 2015 Molecular and clinical aspects of the target therapy with the calcimimetic cinacalcet in the treatment of parathyroid tumors. Current Cancer Drug Targets 15 563-574. (doi:10.2174/156800961566 6150602143041)

Peverelli E, Mantovani G, Vitali E, Elli FM, Olgiati L, Ferrero S, Laws ER, Della Mina P, Villa A, Beck-Peccoz P, et al. 2012 Filamin-A is essential for dopamine $\mathrm{d} 2$ receptor expression and signaling in tumorous lactotrophs. Journal of Clinical Endocrinology Metabolism 97 967-977. (doi:10.1210/jc.2011-2902)

Savoy RM \& Ghosh PM 2013 The dual role of filamin A in cancer: can't live with (too much of) it, can't live without it. Endocrine-Related Cancer 20 R341-R356. (doi:10.1530/ERC-13-0364)

Savoy RM, Chen L, Siddiqui S, Melgoza FU, Durbin-Johnson B, Drake C, Jathal MK, Bose S, Steele TM, Mooso BA, et al. 2015 Transcription of Nrdp1 by the androgen receptor is regulated by nuclear filamin A in prostate cancer. Endocrine-Related Cancer 22 369-386. (doi:10.1530/ ERC-15-0021)

Scillitani A, Guarnieri V, De Geronimo S, Muscarella LA, Battista C, D'Agruma L, Bertoldo F, Florio C, Minisola S, Hendy GN, et al. 2004 Blood ionized calcium is associated with clustered polymorphisms in the carboxyl-terminal tail of the calcium sensing receptor. Journal of Clinical Endocrinology and Metabolism 89 5634-5638. (doi:10.1210/ jc.2004-0129)
Stossel TP, Condeelis J, Cooley L, Hartwig JH, Noegel A, Schleicher M \& Shapiro SS 2001 Filamins as integrators of cell mechanics and signaling. Nature Reviews Molecular Cell Biology 2 138-145. (doi:10.1038/35052082)

Terranegra A, Ferraretto A, Dogliotti E, Scarpellini M, Corbetta S, Barbieri AM, Spada A, Arcidiacono T, Rainone F, Aloia A, et al. 2010 Calcimimetic R-568 effects on activity of R990G polymorphism of calcium-sensing receptor. Journal of Molecular Endocrinology $\mathbf{4 5}$ 245-256. (doi:10.1677/JME-10-0034)

Varshney S, Bhadada SK, Saikia UN, Sachdeva N, Behera A, Arya AK, Sharma S, Bhansali A, Mithal A \& Rao SD 2013a Simultaneous expression analysis of vitamin D receptor, calcium-sensing receptor, cyclin D1, and PTH in symptomatic primary hyperparathyroidism in Asian Indians. European Journal of Endocrinology 169 109-116. (doi:10.1530/EJE-13-0085)

Varshney S, Bhadada SK, Sachdeva N, Arya, AK, Saikia UN, Behera A \& Rao SD $2013 b$ Methylation status of the CpG islands in vitamin D and calcium-sensing receptor gene promoters does not explain the reduced gene expressions in parathyroid adenomas. Journal of Clinical Endocrinology and Metabolism 98 E1631-E1635. (doi:10.1210/ jc.2013-1699)

Vezzoli G, Tanini A, Ferrucci L, Soldati L, Bianchin C, Franceschelli F, Malentacchi C, Porfirio B, Adamo D, Terranegra A, et al. 2002 Influence of calcium-sensing receptor gene on urinary calcium excretion in stone-forming patients. Journal of the American Society of Nephrology 13 2517-2523. (doi:10.1097/01.ASN.0000030077.72157. D2)

Vezzoli G, Scillitani A, Corbetta S, Terranegra A, Dogliotti E, Guarnieri V, Arcidiacono T, Macrina L, Mingione A, Brasacchio C, et al. 2015 Risk of nephrolithiasis in primary hyperparathyroidism is associated with two polymorphisms of the calcium-sensing receptor gene. Journal of Nephrology 28 67-72. (doi:10.1007/s40620-014-0106-8)

Wittenveen JE, Hamdy NA, Dekkers OM, Kievit J, van Wezel T, The BT, Romijn JA \& Morreau H 2011 Downregulation of CASR expression and global loss of parafibromin staining are strong negative determinants of prognosis in parathyroid carcinoma. Modern Pathology 24 688-697. (doi:10.1038/modpathol.2010.236)

Yano S, Sugimoto T, Tsukamoto T, Chihara K, Kobayashi A, Kitazawa S, Maeda S \& Kitazawa R 2003 Decrease in vitamin D receptor and calcium-sensing receptor in highly proliferative parathyroid adenomas. European Journal of Endocrinology 148 403-411. (doi:10.1530/eje.0.1480403)

Zhang M \& Breitwieser GE 2005 High affinity interaction with Filamin A protects against calcium-sensing receptor degradation. Journal of Biological Chemistry 280 11140-11146. (doi:10.1074/jbc. M412242200)

Received in final form 13 November 2016

Accepted 21 November 2016

Accepted Preprint published online 21 November 2016 http://jme.endocrinology-journals.org DOI: 10.1530/JME-16-0184
C 2017 Society for Endocrinology Printed in Great Britain
Published by Bioscientifica Ltd. 